\title{
Teaching And Learning For Artists And Their Works Of Art Within The Market Model: A Discussion Of Value
}

\author{
Daniel Atanasovski, Axis Productions \& Academy, Macedonia \\ Melinda Bender, Utah Valley University, USA \\ Miles Fulwider, Beyond the Music Media, USA \\ Michael Stemkoski, Utah Valley University, USA \\ Tricia Walker, Delta State University, USA
}

\begin{abstract}
This broad-based article discusses teaching and learning that connects artists and their creative art products with the capitalistic system within the market valuation model for a created product that is particularly associated with artists. This general discussion is transferable across teaching and learning disciplines involving the market valuation model for a created product. Further, the article is mainly concerned with the teaching and learning surrounding the valuing and selling of a creative art product within the market place for artists and their created art product. This article offers benefits to artists and teachers by providing them with a positive understanding of the market valuation model as one of the gatekeepers in determining the value of an artist and their created art product in the market place. This article discusses the broad-based facilitating valuation capabilities of the market as well as the market's valuation limitations for artists and for their art products.

Due to the market valuation process for an artist's work in a capitalistic market driven system, the artist may determine that there is a need to consider adding other assets or resources as part of the artist's "toolkit" (assets, resources, experiences, self-directed learning, additional education, conducting research and investigation, work for hire methods, relationship building techniques, and other supplementary broad-based professional capabilities). Finally, the market valuation as gatekeeper may not be a perfect system in servicing artists, their art work, and valuing the artists' "toolkit." Again, artists may need to consider developing additional assets, resources, experiences, self-directed learning, additional education, conducting research and investigation, work for hire methods, relationship building techniques, and other supplementary broad-based professional capabilities over time as part of their focused "toolkit" that the market may value based on anticipated market conditions, projected period factors, current changes in technology, bias, timing, relentless self-promotion, relationship building techniques, "salesmanship," and other factors. Effective "salesmanship" (ability to sell) becomes an essential component along with valued execution by artists and their art product for gaining operative distribution with positive cash flows and profit sustaining abilities for artists and their art products in the market place.
\end{abstract}

Keywords: Creating Works of Art; Market Model; Business Model; Teaching and Learning Across Disciplines; Self-Directed Learning; Psychic Income

\section{INTRODUCTION}

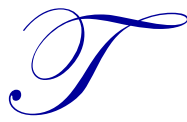

his article assumes that the art product was created (made) by artists. The term artist in this article refers to a person who produces works of art that are primarily subject to a broad-based artistic condition. The terms creative product, artistic product, and art product are considered interchangeable throughout this article. The market system may interact with the artist by positively or negatively valuing the artist and the art product in the market place. There are hundreds or even thousands of market models 
that attempt to explain or predict the behavior of one or more aspects of a market place product valuation. There are a number of factors, both tangible and intangible, that the market may consider in valuing artists and the artists' art products that may generate a positive or negative value in the market place.

Artists may want to familiarize themselves and cooperate with the market model instead of frequently attributing the market for not preferring their works of art over other artists and their creation, or for the market not wanting to favor an artist in comparison of rewarding another artist and their works of art. The market has its reasons for valuing or discounting an artist and the art product. This article allows the artist to objectively consider the market model in valuing artists and their works of art. The article suggests and teaches that artists may want to welcome the services of the market model as one alternative and as a possible indicator in being able to sell themselves as an artist and create their art product. Also, the article suggests that there are benefits to the artist in considering the market model and in gaining an understanding of the benefits of how the market model may help service artists in selling and valuing their art products in the market place.

Connecting a teaching and learning discussion within the market model for artists and art products has selling benefits and self-sustaining implications for artists and their art products as well as a learning benefit for students and instructors. This article emphasizes that it is important to have artists, students, and instructors become aware of the market model and view the market model as being of service to artists as one of the gatekeepers in the selling and sustaining process for artists and for their creative art products.

Whether the art product is a song, book, digital book, novel, fiction or non-fiction work, screenplay, sculpture, painting, movie, documentary, musical composition, or other piece of art, the market system will be beneficial in the market place and to the artist and art product in its sustaining and non-sustaining functions. The artist will learn in this article that the market does make errors in judgment, but the artist should not make the market errors and exceptions the rules that they follow. An error in judgment by the market is not the necessary standard to be followed by an artist in the market place. Trying to follow an exception to a rule and following a market error in the market model is often an ineffective revenue or sales generating process for the artist and the art product. The artist will learn that the market model is not a perfect system, and the market wants, what it wants, when it wants it.

It is in the doing by an artist and the appropriate action taken by the artist within the market model with a valued idea that valued art is created by the artist in the market place. The artist may be a gifted director or delegator which the market may value. The market values the artist being responsible to meet deadlines and other important capabilities by an artist. An artist as part of the market value model will want to learn how to follow a schedule. The market may value an artist who stays on budget and produces an art product of worth in the market place for consumers with quality, on schedule, and within budget.

Other times, the market may offer positive results for an artist's intangible gift, such as knowing how to develop effective relationship building, "salesmanship," directing, delegation and hiring abilities, and being singleminded with an obsession, or the market may not reward relationship building or single-minded obsession by an artist. In certain cases, the artist may be rewarded by the market because the market has valued the gifted nature of the artist's skills (research, investigation, and other abilities). Artists may have the gift to be transcendent in their creations of an art product that sells and that has value in the market place.

There are artists who may not be comfortable creating and working within a schedule or deadlines. They may operate within their own deliberate creative action sometimes referred to as obeying their own muse (psychic income, self-worth, or nonmonetary satisfaction that money cannot match). This article suggests that both the market model and a creative outlet by an artist are necessary to economically sustain an artist and the creative process.

Certain artists may create an art product without thinking about money and without being concerned with selling their art. For artists to sustain themselves economically within the market model, they may need to find an economic balance within the creative commercial process. There are practical as well as serendipitous situations for artists and their art products. First, enthusiasm comes in many styles from quiet persistence to vigorous drum beats with a deep belief in a valued idea for the market place. Second, ultimately, the artists needs to be able to tuck the 
brand-new concocted creative idea and brainstorm under their arms and step out boldly into a cold, uncaring world, and into the market place to make the creative idea happen. Realistically from a practical stand point, there are necessary artist skills, standards, and structures that are desirable in the market place to make the creative idea happen for artists and their companies. This may be the roughest and the toughest most challenging part of the creative process (Emmerling, 1991, p. 17).

It is possible for artists to plan and to generate other sources of income in the market place outside of their specific art product that will allow these artists to continue to create their art because they are not fully dependent on their art creation for their income and are able to create freely and independently within the market place. There are artists who go to sleep at night worrying if they will forget how to play their horn in the morning. The first thing they do every morning is to grab for their horn, and they play music with their horn every morning to make sure they are still able to play. In this sense, they are both tortured and nurtured by their art form.

Many artists may not function well in the market model because they cannot take action or compute the economic advantages of creating art as a commercial product. These artists may suffer economically under the market model, but the work they create may benefit society, though many times, after their life-time. As in the above example, there is the "tortured artist" who creates because their art form is humanly necessary, but the art form is both torturing and nourishing to the artist. It is like eating or the grabbing for their horn and playing their horn every morning. They cannot compute how the economic system works.

There are artists who the market model rewards because they offer the market place that wanted gimmick, ego, and fame. Still for other artists, it is the struggle of the balancing act of the economics of the art with their love for the creative process. Even though there are many different aspects of the creative process, this article concentrates on the benefits of using the market model as one of the gatekeepers for an artist and their created art product.

Consumers may want to hire (commission) artists to create a piece of art. As previously stated, the market system will either reward or penalize the artist in the market place based on a number of factors. Markets create wealth, and they do not redistribute wealth. The market exchanges wealth through value by means of market valued transactions that are sometimes referred to as deal making or a decided upon exchange for value.

\section{CREATE THE ART OR PRODUCT BY SPECULATION}

Making the art product and then trying to sell the product has risks associated with this speculation business endeavor because the artist's art product may not be accompanied by a positive valued demand in the market place. In fact, the market may not place any value on the work of art even if the artist decides to offer the art product to the market for free. Because the artist wants to offer an opportunity as a noble gesture to everyone in the market does not mean, necessarily, that the artist will be rewarded for the gesture by an increase in market value for the work of art. The entire process, method, or production of making art and then trying to sell the work of art is considered speculation. The artists are hoping that their art products will be considered as having value in the market place. The supportive market value and demand is an added bonus for these artists. The artists are hoping that there are enough consumers present in the market place that they will be valued as artists, and the created art work will have value in the market place whether it is a song, book, digital book, novel, fiction or non-fiction work, screenplay, sculpture, painting, movie, documentary, musical composition, or other piece of art.

Artists may expect that there are enough consumers in the market place who will like what was created to allow the art product and artist to be sold for value. The market values them as artists and the art products by finding ample consumers in the market place who are willing to pay a price to obtain the created product. The artists are anticipating, wishing, and dreaming, with or without an action plan, that the art products produced will serve the market and customers well and be valued in the market place. The artists are optimistic that there are consumers who will make a purchase of the created art product for value. The market model helps to determine if the artists and their art products are valued in the market place as the market considers many important market factors besides the hoping, wishing, or dreaming by the artist that the art product will be successful. 
The artist may feel that there is no other choice but to get started as soon as possible, and no other choice, but to speculate within the market by creating the art product through ideas and with an executable business model that will work. The artist might decide to initialize the creation before the artist or creator knows whether there is a demand or market value for the art product. The artists may want to prove that they have the capability and capacity to produce an art product with value in the market place. It is not only important to produce an art product on time or as scheduled with quality and within budget, but it is also important to know the art product will be distributed and sold in some manner to generate revenue and sales with positive cash flow for profit. This may require extensive research and investigation into how the market works so as to gain maturity versus appearing as an amateur, therefore, possibly increasing the probabilities for a successful product launch.

Artists may ethically feel the need to prove that they can produce on time with quality, as scheduled, and within budget. The artists are not touting what they can or cannot do regarding the producing of the art product. An artist may feel it is not acceptable to have to apologize, after the fact, that the work could not be completed, or that a piece of art could not be finished on time with quality, as scheduled, and within budget, or as commissioned. Again, the market may value art production by an artist who is on schedule, with quality, and within the budget, and the artist and the art product may seek effective distribution to sell in the market place with positive cash flow and profit. Conversely, the art product may or may not sell in the market, and the market model may or may not favorably value the artist and the art product with effective distribution.

To have creative value be discovered by the market, the market may search out and value the necessary skills and craft needed in the creative process in creating, making, and producing art products that have market value from a particular artist. This may be the situation whether the art product was commissioned, or the product creation was hired and certain tasks directed and delegated. The market may or may not value the artists' ability to direct or delegate. In still other cases, there is no choice, and the art product has to be created and sold to sustain the artist and the created art product.

\section{AGENTS AND MANAGERS IN THE MARKET PLACE}

An agent or manager in the market place is routinely established in the market place to help an artist with an art product if there is a tangible or intangible profit motive. The market place provides incentives to agents and managers to help mentor an artist and their art product. When capable, the agents and managers help, but the main reason artists are received by agents and managers is so the agents and managers can evaluate and assess the artist and the created art product for value to determine if money can be made with a certain probability and with acceptable cost factors for the agency and agent/manager (Goldman, 1983, p. 85). An agency is, in effect, a joint venture and an alliance with a working relationship with the artist for value. Agents and managers may serve as gatekeepers in the market place to help determine what will and will not make them money in the market for value. It matters to the agent/manager on whether they are right or wrong in selecting an artist to represent as a client. It does not matter to the market whether the agent/manager is right or wrong. The decisions that are being made concern positive cash flows and profits for the agency. The agent and manager try to correctly select an artist client because the salaries and the compensation levels of the agent/manager may be dependent on the successful decisions of the agent and manager in selecting the correct artist client. Their reputation depends on being able to pick winners and the successes within their agency. The agency is required by the market to be prudent in sustaining its services to serve the market and to be true to its mission.

Part of an artist's profession is to sell what the artist creates. The artist can have someone sell for them, such as an agent and manager. If the agent and manager value the product and trust that an artist can make money in the market place, then the agent and manager encourage the artist to create and produce. The artists and agents along with the managers work together to form an alliance or joint venture in trying to understand why, how, and what will make money for creative value in the market place. The agents and managers make money by selling the artist as well as the art product. The artists are hopefully sustained by the effective agent/manager with an artist relationship where the artist and agency generate positive results and performances that the market rewards. One of the main reasons for artists to have an agent/manager is to allow the artists to focus solely on their craft. For example in the music industry, the challenge now is that far more producers and mixers are competing for less work. 
They have smaller budgets (costs) than ever before, and the artists, musicians, producers, mixers, and engineers along with the agents and managers are the ones who are actually making the product that everyone else is selling (Weiss, 2012).

\section{CREATE THE ART OR PRODUCT BY PRE-SELLING}

If an artist raises the investment capital allowing resources and money to be allocated and placed into a budget to commission a piece of art, then the commissioned art piece is pre-sold. However, when the payment is made to the artist in advance, some of the risk is transferred from the artist back to the person or entity that made the advanced payment or investment in the artist and the art product. The artist has a liability or obligation to perform by producing the commissioned piece of art. If the artist does not perform as contracted, the artist is indebted to return the cash received in advance to the investor. The artist records the cash received in advanced as unearned income or as a deposit that is a liability to the artist until there is performance by the artist under the contract.

\section{THE MYTH}

An artist may have an idea for a song, screenplay, book, play, documentary, sculpture, painting, movie, musical composition, or other piece of art, but having an idea that is certain that will sell is a myth. The idea in and of itself may not be enough for an entire song or screenplay, but the idea is a start for one scene, or one point in the song, or chapter. Having an idea is a worthy start because art starts with an idea. An idea is an admirable start that necessitates successful development further into a song, book, digital book, novel, fiction or non-fiction work, screenplay, sculpture, painting, movie, musical composition, or other piece of art.

Idea development and the project management of a production process that create value are important to the market place. A story or song has to be developed to be heard. The market place requires ideas that are effectively developed into successful market valued art projects. Ideas are prerequisites for an opportunity to be proven in the market place to create value (Fisher \& Hoffmans, 2009, p. 76).

Because of the Internet, artists can be more risk averse and test (beta test) what may work in the market place and what art work has value in the market place before a large amount of money (sunk costs) is placed into producing an idea that may not work in the market place. The question is why the artist wants to create the art product versus what or how to create the art product. The artists may have to be careful not to give investors the impression that the artists are creating art projects to fashion a job for themselves with investor capital which can result in legal and ethical issues. Again, the market may value a work of art and the artist incorrectly in the market place. The market may reject what was thought of as a great idea by an artist that was seriously being considered for development, production, and for distribution by an artist in the market place. Knowing how to develop an idea and knowing how to sell ideas are aspects of the creative equation that are combined with fundamentally solid artists who know their craft.

Mr. Robert Redford, the well-known actor, writer, and director, relates his thoughts that are inscribed on a wall at the celebrated Sundance Resort located in the mountains at Sundance, Utah: "This place in the mountains, amid nature's casualness toward death and birth, is the perfect host for inspiration of ideas: harsh at times, lifethreatening in its winters of destruction, but tender in attention to the details of every petal of every wildflower resurrected in the spring. Nature and creativity obey the same laws, to the same end: life" (Redford, 1998).

Like nature's harshness and beauty, it is the action that the artist is willing to take as an artist and the requisite to distribute the art product that the market tends to positively value. The successful process in creating art and an idea is important to the market and to the value of the art product. If the market determines that the art and an artist has value, the market offers opportunities to read, hear, and see the valued creation come to life. It is in the doing, accomplishing, and creating the art product for the market according to an effective business model that the market values in an artist and in the art product.

The market decides, and the market does not care that the market is being criticized for making an error in judgment. The market and commercialism can be biased about a work of art or an artist. The market does not care if 
it is right or wrong about the allocation of resources for an artist or work of art. The discussion on whether the market is doing its job without mistakes is an arguable point. Individuals within the market make decisions. It is one person's opinion or a team's decision, and people can make mistakes and make errors in judgment. The market knows that it can be incorrect, but it does not care even though the market is trying to be correct about its valuation of an artist and the work of art. The market is not socially redeeming. Furthermore, the market is often neutral to ethics and legal matters, and this is one of the reasons why laws are added along with regulations and contracts to try to improve the market where some people may feel that the market may be lacking in social responsibility, moral duty, and ethics. The market exists to serve others. It does not discriminate in and within itself when it creates wealth. Effective judgment, relentless self-promotion, timing, and biased assessment of the worth of the market model in doing its job are additional factors that may add personal standing and credibility to the helpfulness of the market model.

Adding laws, regulations, and contracts may allow people to sense that the market is more socially conscious with a behavioral standard. However, it does not matter to the market what an artist personally thinks about a work of art, nor does the market care about the artist's opinion. The market will decide the value of artists and their art products in the market place. The market functions to serve customers and the artist to receive value for the use of gifts, talents, and crafts through exchanged valued transactions.

The market is a powerful force that will decide on the value of the art product and the value of the artist's performances along with the artist's results. The market will help determine if others in the market find the artist and art work valuable enough to generate a positive cash flow by making enough money through valued transactions and with an exchange for value to sustain the artist.

The renowned screenwriter William Goldman, an American novelist, playwright, and Academy Award winning screenwriter, stated in his book, "Nobody knows anything. Not one person in the entire motion picture field knows for a certainty what's going to work" (Goldman, 1983, p. 39). Every time out it is a guess and if you're lucky, an educated one.

There may be a myth in regards to the market value in the artist deciding to produce a creative product for one's own desk. The market demand for an artist or artist's art product may consist of only several people or one person. The market for an "own desk" art product may not be large enough in demand for the art product or for an artist to make a satisfactory return on investment, in other words, make money. Often, an artist may operate the creation of art as a hobby more than a business venture. If having a hobby is an objective and default process for an artist, then the artist is willing to accept the hobby aspect of art creation as a goal and as an objective within itself. The hobby concept can be a reasonable choice for creative work. Normally, artists want to have a market of relevance and of more than one or two people to allow the art created product to sustain the artist economically or as an added bonus for generating sales. If the art is a hobby, the creative art may have an added requirement and that is to be subsidized or commissioned as supplemental income. Hobby sales may satisfy the artist and a few other people that are acquainted with the artist's work (Fisher \& Hoffmans, 2009, p. 76).

However, if the objective and goal of the artist and the art work is to find a way to make art that is valued by the market and to have the art work and artist economically sustained, the art offered to the market must be of value in the market place and have demand. There are ways to take action to allow the artist and the work of art to make money in the market place. It is hard work to create valued art that makes enough money to sustain an artist professionally on a day-to-day basis. It will take time to produce art that is valued in the market place and for the artist to create a brand. This effort and passion may require a steep learning curve. It helps if the artist is singleminded, tenacious, and persistent. The artist will normally have to work hard and take action to produce art that meets a schedule and deadlines, is of necessary quality, and stays within budget, or the art will not be produced. There may be a need to be obsessed with the art product within the creative process to bring an art product to life.

\section{SELLING THE ART OR PRODUCT}

If art is created for what the market values, the ability of the artist and the creation of the art product are valued by the market. The art product and artist have to be sold into the market place. The artist has to learn how to 
create for value and learn how to help sell the art. The market may not be valuing the artist or the art product because of the lack of demand in the market place or too much supply in the market place. This is similar to having a lot of "good" truck drivers or in this case "good" artists (supply), but not having enough trucks to drive or not having enough demand in relation to the supply for the artists' product. In this analogy, there are not enough trucks (supply) to demand more "good" truck drivers, or there are too many available drivers and not enough trucks to drive. The market may view the artist as a supply without the necessary demand in the market for the artist or for the art product (simple law of supply and demand).

As professional artists, there is a need to learn how to sell the work of art, and to know how, what, and why things sell, or are selling. There are two sides to the market equation to allow it to balance and be equal. Giving value first can be the left side of the equation that equals the right side of the equation, and therefore, secondly, receiving value. This is one of the ways that the market system may work for the artist. Giving of value = Receiving of value.

\section{MARKET SYSTEM AND THE ART OR PRODUCT}

Artists create an art piece within the market place model under the capitalistic system, first and foremost, for other people. Art is created for the artist as well as for the market place. Again, there are two sides to the equation for value. This joint satisfaction means creating the value of the art and product and placing this on the left side of the equation, or the value that is being given, and placing what is being received for what is being given on the right side of the equation. In market driven products, customers determine market value, and the transaction is a giving and receiving of value.

\section{Action Plan for Art or Product}

- Investigate and test the market to determine if an artist is producing what the market wishes to value, and if the market will value the artist and the work of art with positive cash flow. However, market tests are not infallible and may be, at best, indicators of anticipated value in the market place or an educated guess.

- Take action to try to create and sell the art or product. Be committed to selling and making money on the artistic product in the market place.

- Know what it takes to be successful in a business and in creating value as an artist in order to sustain growth, positive cash flow, and profit (research and investigation).

- Define through a realistic self-assessment what is needed to give artistic value in the market place that the market will value, and then secondly, what is being received of value in return for what is given.

- Know why, what, and how things are happening in the market place for artists and art products, and the requirements to have an excellent action plan that includes a business and marketing plan for the artist and the art product in order to receive value in the market place as an exchange of value (Godin, 2010, p. 150). (Note: The market does not try to understand the artists' mentality or the creative process, and the market does not reward artists or the work of art based on intrinsic value alone.)

\section{CONCLUSION}

It is hard work to become better at something and to create value for others by trying to be "good" stewards. The capitalistic system and market models are not perfect or socially redeeming. The system and models do "clean the market house" now and then. Often products that should make it to the market place and may have value do not make it to the market. Other products, for a host of reasons, are rewarded by the market with success.

The market system as part of its equation may or may not value intangibles such as competent persistence and other intangibles. Through the market system, the valued artist and the art product emerges or gets "killed off." The market may not have available space in the market place for the type of artist craft, and the market does not demand the type of art product services that are being produced by a particular artist. Even if the art is free, or the art product is given as a "freemium" product to serve as an opportunity for many by reducing barriers to entry in the market place, the artist and art product may not be valued in the market place (Osterwalder \& Pigneur, 2010, p. 96). 
The market system, in some cases, may reward or penalize prudent sacrifice or may not consider sacrifice by an artist as providing value to the market. The two sides of the equation are the giving side on the left side of the equation and the receiving side on the right side of the equation. The market system likes to reward successes. Furthermore, the market system is a biased gatekeeper and does make mistakes. If the market misses a few art products along the way, the market does not worry; the market system is not perfect or always efficient. The market system may reward and penalize the physical tangibles of the artist and the artist's work. Moreover, the market system may reward and penalize certain intangibles in the artist and the artist's work such as ethics or lack of ethics, philanthropist and non-philanthropist behavior, education or lack of education by an artist, and other dichotomies. Certain artists will transcend and be rewarded by the market and others will not, with the operative words being it depends on the market, the artist, and the art product for the rewards.

One way or another, the market system may not intend to "kill off" a creative product, but it does. Again, it is not a perfect system, and the market wants, what it wants, when it wants it. As a final summary, and for an example of an art product created by an artist offering free educational opportunities through music, please search on the following link for Rob Mathes Beyond the Music www.robmathesbeyondthemusic.com

\section{AUTHOR INFORMATION}

Daniel Atanasovski is co-owner of award winning Axis Productions \& Academy offering video editing, postproduction, and visual effects for movies, documentary film, and TV commercials in Skopje, Macedonia and throughout the rest of the world. E-mail: daniel@axis.com.mk

Melinda Bender is a full Professor of Basic Composition at Utah Valley University in Orem, Utah. She has been teaching for over 15 years. She creates writing projects with artists and music themes. E-mail: benderme@uvu.edu (Corresponding author)

Miles Fulwider is a producer and audio engineer and has worked with artists at Jazz at Lincoln Center (JALC), Avatar Studios in New York City, and he is co-owner of Beyond the Music Media (BTMM). He has worked with artists Norah Jones, Willie Nelson, Wynton Marsalis, Rob Mathes, Joe Bonadio, Tricia Walker, and others. E-mail: milesf@me.com

Michael Stemkoski is a full Professor of Accounting at Utah Valley University in Orem, Utah. He has been teaching for over 20 years. He works with artists and their music projects. E-mail: stemkomi@uvu.edu

Tricia Walker is the Director of the Delta Music Institute (DMI) at Delta State University in Cleveland, Mississippi. She is an award winning Nashville singer songwriter, producer, teacher, and musician. Her songs have been recorded by some of the top recording artists in the country. E-mail: twalker@deltastate.edu

\section{REFERENCES}

1. Emmerling, J. (1991). It only takes one: How to create the right ideal and then make it happen. New York, New York: Simon \& Schuster.

2. Fisher, K. \& Hoffmans, L. (2009). The ten roads to riches: The ways the wealthy got there and how you can too. Hoboken, New Jersey: John Wiley \& Sons, Inc.

3. Godin, S. (2010). Linchpin: Are you indispensable? New York, New York: Penguin Group.

4. Goldman, W. (1983). Adventures in the screen trade: A personal view of Hollywood and screenwriting. New York, New York: Warner Books Hachette Book Group.

5. Osterwalder, A. \& Pigneur, Y. (2010). Business model generation. Hoboken, New Jersey: Wiley \& Sons, Inc.

6. Redford, R. (1998). Wall inscription, Sundance Resort, Sundance, Utah.

7. Rob Mathes Beyond the Music (2011). Beyond the Music Media. Retrieved from http://www.robmathesbeyondthemusic.com/test $2 /$

8. Weiss, D. (2012, July 15). Do producer managers help your career? An in-depth report. Sonics Scoop. Retrieved from http://www.sonicscoop.com/2012/07/15/do-producer-managers-help-your-career-an-indepth-report/ 